\title{
Spore Germination Self-Inhibitors from Plant Pathogenic Fungi*
}

\author{
Tamio Ueno, Hisashi Miyagawa, Tetsu Tsurushima** and Masafumi Inoue*** \\ Division of Applied Sciences, Graduate School of Agriculture, Kyoto University, Kitashirakawa, \\ Sakyo-ku, Kyoto 606-01, Japan \\ ${ }^{* *}$ Faculty of Commercial Science, Han-nan University, Amamihigashi, Matsubara, Osaka 580, Japan \\ ***Central Research Laboratory, Dainihon Jochugiku Co., Ltd., Toyonaka, Osaka 561, Japan
}

(Accepted August 20, 1997)

What kind of mechanism regulates conidial germination of filamentous fungi?

The first event in the formation of a new fungal colony is the germination of a spore, which is one of the most crucial events in the life cycle. The infection of a plant by a parasitic fungus and the resulting production of disease is initiated, in most instances, by a spore germinating within or near the potential host plant. Thus, for plant pathogenic fungi in particular, the elucidation of the spore germination mechanism is likely to be significant in devising strategies for crop protection.

Although spore germination is regulated by several physical factors such as temperature, moisture, and light in a favorable environment where water is an indispensable factor, it has been proposed that certain chemical signals also assist or promote spore germination. For example, some chemical components from the host plant may promote conidial germination of parasitic fungi. ${ }^{1)}$ Despite the lack of direct chemical evidence, it is reasonable in an ecological context that such a promoting factor participates as a chemical signal between the host and the parasite. What kinds of signals are transmitted to induce the spores to germinate, responding to favorable environmental conditions? As an answer to the question, spores of some fungi have been shown to contain endogenous self-inhibitors which initiate (de-repress) germination by leaching from the spores themselves.

In general, mature spores removed from the parent mycelium begin to germinate readily when dispersed in water. However, in several examples, it has been reported that the percent germination is dependent on the population of spores. In the case of the strawberry anthracnose fungus, more than $90 \%$ germination is observed at $10^{4}$ spores $/ \mathrm{ml}$; on the other hand percent germi-

\footnotetext{
${ }^{*}$ This article is the English translation of the review article originally published in Japanese in Shokubutsu Byogai no Kagaku, ed. by A. Ichihara and T. Ueno, Japan Scientific Societies Press, Tokyo, pp. 203-214, 1997.
}

nation decreases as the population is increased. Germination is almost completely inhibited at $10^{7}$ spores $/ \mathrm{ml}$, as shown in Fig. 1.

Inhibition at high conidial concentration is not reduced by addition of $\mathrm{O}_{2}$, but it is depressed by washing the conidia with water to remove the exudates. The washing effect is demonstrated from the data shown in Fig. 2: $20 \%$ germination is increased to $80 \%$ by repeating the washing procedure at $2 \times 10^{6}$ spores $/ \mathrm{ml}$ of the strawberry anthracnose fungus.

An induction of germination by washing suggests the participation of germination inhibitor(s) which is exuded into the environment at high concentrations under dense conidial populations. Presumably, germination under dense population conditions would be disadvantageous for survival because of nutrient competition during subsequent vegetative growth. Thus, the germination inhibitor exuded from the conidia functions to retard germination until a favorable environment is encountered.

This exuded inhibitor is likely to be an endogenous factor contained in the conidia themselves which regulates their germination mechanism. It is easily exuded from the conidia when they are dispersed under moist conditions. By repeated washings the inhibitor is removed from the conidia so as to initiate germination. The inhibitor(s) may be regarded as a kind of a fungal hormone or an endogenous factor that controls the quiescence of the spores.

Currently, self-germination of germination has been observed in over 60 examples. Early studies by Allen provided evidence that a regulatory substance plays an important part in the germination of uredospore of the rust fungus, Puccinia graminis f. sp tritici. ${ }^{3)}$ He referred to the active principle as a germination self-inhibitor which is contained in water extracts of uredospores. The structure of this active principle was later elucidated by Macko, who performed the isolation and 


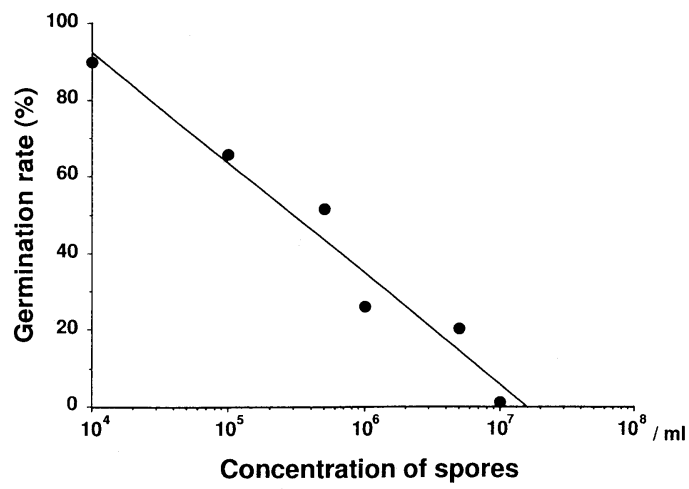

Fig. 1 Relationship between germination rate and Colletotrichum fragariae spore density.

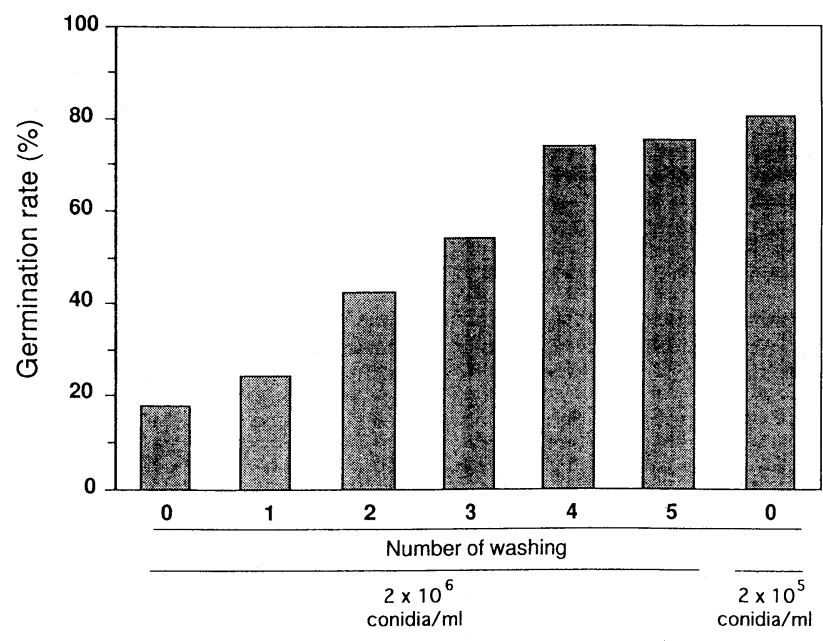

Fig. 2 Effect of washing on spore germination.

identification of native self-inhibitors in several species of fungi. ${ }^{4)}$ These self-inhibitors have been shown to exhibit sporostatic activity at extremely dilute concentration, and their effects are reversible and specific such that only spore germination is inhibited but not hyphal growth. Characterization of self-inhibitors will likely provide us with new targets for developing genuine antifungal agents. In addition, analysis of their mode of action is also likely to disclose the mechanism of release from dormancy to germination not only in fungal spores but also in seeds of higher plant. In this article, advances in the chemical characterization of selfinhibitors will be described from the perspective of natural product chemistry.

\section{Germination Self-inhibitors from Uredospores of Rust Fungi}

Rust fungi, obligate parasites belonging to the basidiomycetes, produce uredia which look like clumps of iron rust on the surface of host leaves. They parasitize a wide range of crop plants but highly specific combinations are observed in their host selections.
The most extensive research on self-inhibition of spore germination has been conducted with rust fungi. However, difficulties with spore collection have always presented experimental restrictions, because their obligate nature does not allow large scale spore production in artificial culture condition. Additionally, plural spore morphologies such as uredospore, teliospore, pycniospore and aeciospore, are induced in some species of rust fungi, depending on a complicated life cycle based on parasitism of alternate hosts. Most research on the characterization of the self-inhibitor have been performed with the uredopspores which can be comparatively easily collected. As described before, Allen provided the first explanation that rust spore germination is regulated by an endogenous factor contained in the spores themselves. ${ }^{3)}$ His report in 1955 , based on detailed experimental observations, demonstrated that the germination of the uredospores of $P$. graminis f. sp. tritici dispersed in water is inversely dependent on the concentration of spores in water. Since the percent germination was increased by replacing the original water containing the uredospores with fresh water, it was concluded that a chemical factor, referred to as a germination self-inhibitor, was exuded from the uredospores into the original water. The structure of the self-inhibitor from P. graminis was elucidated as methyl cis-ferulate (1) from mass spectrometric analysis by Macko et al. who obtained a small amount of the purified active principle by silica gel thin layer chromatography (TLC) of the water extract of a large number of collected uredospore. ${ }^{4)}$ The presence of an endogenous germination inhibitor in the oat rust fungus, Puccinia coronata f. sp. avenae Fraser et Led., had been indicated by Naito et al. ${ }^{5)}$ We reinvestigated the results of their experiment, isolated the active principle from the uredospores of the fungus and identified it as methyl cis-3,4-dimethoxycinnamate (2). ${ }^{6}$ ) This species of rust fungus is also an obligate parasite. Relatively large amounts of uredospores were collected from the infected leaves of the Pc 38 cultivar of oat (Avena sativa L.), which had been excised, washed and<smiles>COC(=O)/C=C/c1ccc(O)c(OC)c1</smiles>

1<smiles>COC(=O)C=Cc1ccc(OC)c(OC)c1</smiles>
3<smiles>COC(=O)/C=C/c1ccc(OC)c(OC)c1</smiles><smiles></smiles>

4
Fig. 3 Self-inhibitors from rust fungi and their analogs. 
incubated for $48 \mathrm{hr}$ in a dark moist chamber at $25^{\circ} \mathrm{C}$. More than $90 \%$ germination was observed when the collected uredospores $(5 \mathrm{mg})$ was dispersed in $10 \mathrm{ml}$ of water in a petri-dish. Conversely the germination was completely inhibited when the concentration of the spores was increased to $40 \mathrm{mg}$ in $10 \mathrm{ml}$ of water. However, spore germination was stimulated by washing the uredospores $(40 \mathrm{mg})$ with water $(40 \mathrm{ml})$ for $20 \mathrm{~min}$ followed by adding another $40 \mathrm{ml}$ of fresh water after removal of the first washing water. This result provided an indication that a spore germination inhibitor is contained in the original washing water of the uredospores in the denser population.

Our chemical analysis of the spore germination inhibitor was performed as follows ${ }^{6}$ : uredospores of $P$. coronata f. sp avenae Fraser et Led. were stirred in distilled water at $20^{\circ} \mathrm{C}$ for $20 \mathrm{~min}$ in darkness. The filtrate of the uredospores was extracted three times with an equal volume of water. An ether extract was concentrated and purified by preparative TLC to give the crude self-inhibitor, which was subjected to HPLC to give two major peaks corresponding to isomers formed because of their unstable structures. The self-inhibitors in the extract was efficiently detected by the TLC plate bioassay established in our laboratory. ${ }^{6)}$ A portion of the concentrated extract was spotted onto a thin-layer silica gel plate and developed with a suitable solvent system. The plate was thoroughly dried to remove the solvent. After moistening the developed plate by spraying with water, uredospores of $P$. coronata were brushed onto the plate to form a uniform dense layer. The plate was then sprayed with a mist of water and incubated at $20^{\circ} \mathrm{C}$ in darkness for $12-16 \mathrm{hr}$ in a moist chamber. Inhibitory activity on the TLC plate was recognized as yellow spots against the fainter colored background where the original color of uredospores was lost due to germination.

Several runs of the isolation procedures yielded the purified active principle with a yield of $45 \mu \mathrm{g}$ from $50 \mathrm{~g}$ of the uredospores. Samples were stored in darkness to prevent isomerization. Structural elucidation of the self-inhibitor was performed mainly by analyses of mass spectrometric data and chromatographic behaviors. The active principle was easily isomerized by UV irradiation during HPLC isolation to an inactive compound which gave the same pattern in EI mass spectroscopy. Mass spectral analyses of the isolated compound gave identical mass spectra to authentic methyl trans-3,4dimethoxycinnamate. This compound, however, did not inhibit spore germination at any concentration. Consequently, the active principle was concluded to be methyl cis-3,4-dimethoxycinnamate (MDC 2), which was confirmed by comparison of the mass spectrum and chromatographic data with those of the synthesized authentic specimen.

MDC has been reported as a self-inhibitor from $P$. helianthi, $P$. antirrhini, $P$. sorghi, $\left.{ }^{7}\right) P$. arachidis, ${ }^{8)} P$. striiformis, ${ }^{9}$ and Uromyces phaseoli ${ }^{10)}$ in addition to $P$. coronata $\mathrm{f}$. sp. avenae. The results of bioassays on glass slides under the microscope indicated that the inhibitory activity $\left(\mathrm{ED}_{50}\right.$ value) of cis-3,4-dimethoxycinnamate for uredospore germination was $12.5 \mathrm{pg} / \mathrm{ml}$, which is the lowest value among those for self-inhibitors of Puccinia species, while the trans-isomer was not active at any concentration. ${ }^{11)}$

The inhibitory activity of MDC and methyl cisferulate is shown in Table 1 ; the latter compound is reported as a self-inhibitor from $P$. graminis, the causal agent of black rust of wheat. ${ }^{4)}$ Each compound exhibits a selective and highly potent activity against the uredospores of the original fungus. Almost the same activities as those of the natural ones were observed in each of the synthesized benzalmalonate analogs ( 3 and 4$)$ in which a stable symmetric structural feature was introduced in order to avoid their isomerization. These stable analogs will be used for studies on the mode of action and structure-activity relationships of the selfinhibitors.

\section{Germination Self-inhibitors from Conidia of Anth- racnose Fungi}

The phytopathogenic anthracnose fungi are a general class of imperfect fungi including Colletotrichum and Gloeosporium species. Sexual generation is not known in most of the fungi, however, they are typically classified as ascomycetes after identification of their perfect stage. Self-inhibitory phenomena of their conidia have been investigated since the beginning of this century and the first example was already reported by Edgarton in 1910 .

Table 1 Inhibitory activity $\left(\mathrm{ED}_{50}\right.$ value, $\left.\mathrm{pg} / \mathrm{ml}\right)$ of the natural self-inhibitors and synthesized benzalmalonate analogs against uredospore germination of Puccinia coronata f. sp. avenae on the microscope-slide assay.

\begin{tabular}{lcc}
\multicolumn{1}{c}{ Compound } & $\begin{array}{c}\text { Puccinia coronata } \\
\text { f. sp. avenae }\end{array}$ & $\begin{array}{c}\text { Puccinia graminis } \\
\text { f. sp. tritici }\end{array}$ \\
\hline Methyl cis-ferulate (1) & 5570 & $180^{\text {a) }}$ \\
Methyl cis-3,4-dimethoxycinnamate (2) & 13 & $3680^{\text {a) }}$ \\
Methyl 3,4-dimethoxybenzalmalonate (3) & 25 & 4160 \\
Methyl 3-methoxy-4-hydroxy-benzalmalonate (4) & 6800 & 270 \\
\hline
\end{tabular}

a) The values were cited from an article by Macko et al. ${ }^{4)}$ 
Edgarton observed a drastic decrease of conidial germination in dense populations of the bean anthracnose fungus, $C$. lindemuthianum. ${ }^{12)}$

The size of anthracnose conidia is smaller than rust uredospores, making it difficult to collect a large amount of the conidia to perform chemical research such as isolation and structure elucidation of the active principles directly obtained from the conidia themselves. However, because of the facultative saprophytic nature of the anthracnose fungi, it is possible to cultivate them in artificial media. Thus, for identifying the germination self-inhibitors of anthracnose fungi, the candidate selfinhibitory substances are first searched for in cultured media, isolated, and structurally elucidated, and then the role of the isolated substances in the germination process is verified by examining whether those substances are present in the germination fluid or not. However, when employing this approach, most careful and precise analysis of conidia is required, since many inhibitory substances are often produced along with the genuine selfinhibitor(s) in the long-term cultured media.

\subsection{Gloeosporone and germination self-inhibitors from conidia of Colletotrichum gloeosporioides $f$. $s p$. jussiaea}

A germination self-inhibitor, named gloeosporone, was isolated by Lax et al. from the conidial germination fluid of $C$. gloeosporioides f. sp. jussiaea pathogenic to a species of weed, water primrose. ${ }^{13)}$ Its planar structure was proposed to be a 2,8-disubstituted oxocane derivative (5) by Meyer et al. ${ }^{14)}$ Total synthesis of the proposed structure was independently performed by Carling et al. ${ }^{15)}$ and Mortimore et al. ${ }^{16)}$ to determine the relative configurations at the 2- and 8-positions on the oxocane. However, the chemical shifts of the methyne protons at the 2- and 8-positions of the synthesized transand cis-compound are different from those of the natural gloeosporone and they suggested that the structure of the
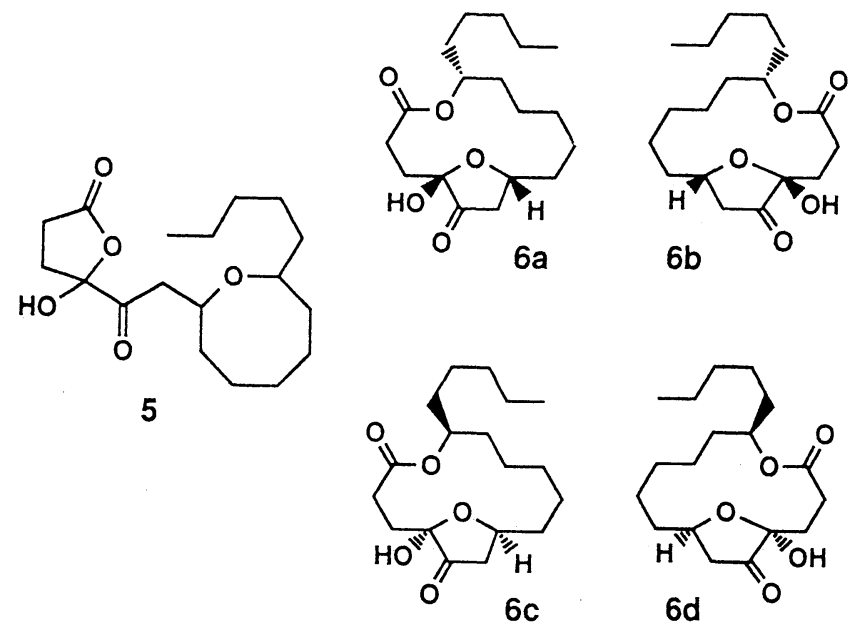

Fig. 4 Gloeosporone : proposed structure (5), revised structure (6a) and synthesized stereoisomers (6a-d).
Table 2 Comparison of percent conidial germination in each concentration of natural self-inhibitors, CG-SI-1 and 2, gloeosporone and its analogs.

\begin{tabular}{lcccc}
\hline \multirow{2}{*}{ Compounds } & \multicolumn{5}{c}{ Concentration (germination \%) } \\
\cline { 2 - 5 } & $100 \mathrm{ppm}$ & $30 \mathrm{ppm}$ & $10 \mathrm{ppm}$ & $3 \mathrm{ppm}$ \\
\hline CG-SI-1 (7a) & 0 & 0 & 0 & 40 \\
CG-SI-1 (7b) & 0 & 0 & 0 & 68 \\
(-)-Gloeosporone (6a) & 49 & 82 & - & - \\
(+)-Gloeosporone (6b) & 44 & 81 & - & - \\
7-Epigloeosporone (6c) & 45 & 82 & - & - \\
13-Epigloeosporone (6d) & 48 & 81 & - & - \\
Control (water) & 82 & 0 & - & - \\
\hline
\end{tabular}

a) Percent conidial germination of Colletotrichum gloeosporioides f. sp. jussiaea was measured with a microscope using each concentration of the compounds indicated.

compound is composed of a 14-membered lactone as shown in (6). Afterwards, the revised structure (6a or 6b) was proposed by Meyer et al., including the relative configuration, from single crystal $\mathrm{X}$-ray analysis and detailed NMR-investigation of the newly recrystallized natural one. ${ }^{17)}$ In order to assign the absolute configurations in gloeosporone (6a or $\mathbf{6 b})$, several stereocontrolled synthetic works were performed. The reported values of the specific rotation of the natural gloeosporone in chloroform have relatively large deviations between $-14^{\circ}$ and $-83^{\circ}$ depending on the reports, which should be attributed to the tautomeric epimerization at 4-position through 7-hydroxy-4,5-diketo structure to result in an equilibrium mixture. Adam et al. reported the synthesis of $(+)$-gloeosporone (6b) by Mitsunobu lactonization of the 7,13-dihydroxy-4,5-diketo C-18 carboxylic acid which was prepared according to the retrosynthetic scheme shown in Fig. 5-1, ${ }^{18)}$ but the optical rotation $[a]_{\mathrm{D}}$ of the synthetic $(+)$-gloeosporone was $+52^{\circ}\left(c=0.71, \mathrm{CHCl}_{3}\right)$, whereas that of the natural one exhibited (-)-value in all cases. Consequently, the structure of the natural gloeosporone (6a) was determined to be (-)-antipode, including absolute configurations $(4 S, 7 R, 13 S)$. Such a unique structure of gloeosporone attracted organic chemists to accomplish its stereoselective synthesis. The first enantioselective synthesis of the natural ( - )-gloeosporone was performed by Takano et al., starting from $(S)$ - $O$-benzylglycidol according to the retrosynthesis scheme shown in Fig. $5-2,{ }^{19)}$ and Schreiber et al. reported the synthesis of the natural one and its antipode. ${ }^{20)}$ In addition, Seebach $e t$ $a l$. and we have also accomplished the synthesis of the $(-)$ and (+)-gloeosporone including their epimers according to the retrosynthesis scheme shown in Fig. $5-3 .^{21-23)}$

In the course of our studies on self-inhibitors, we have extended our studies to isolate self-inhibitors from the anthracnose fungi. After collecting 16 strains of the 


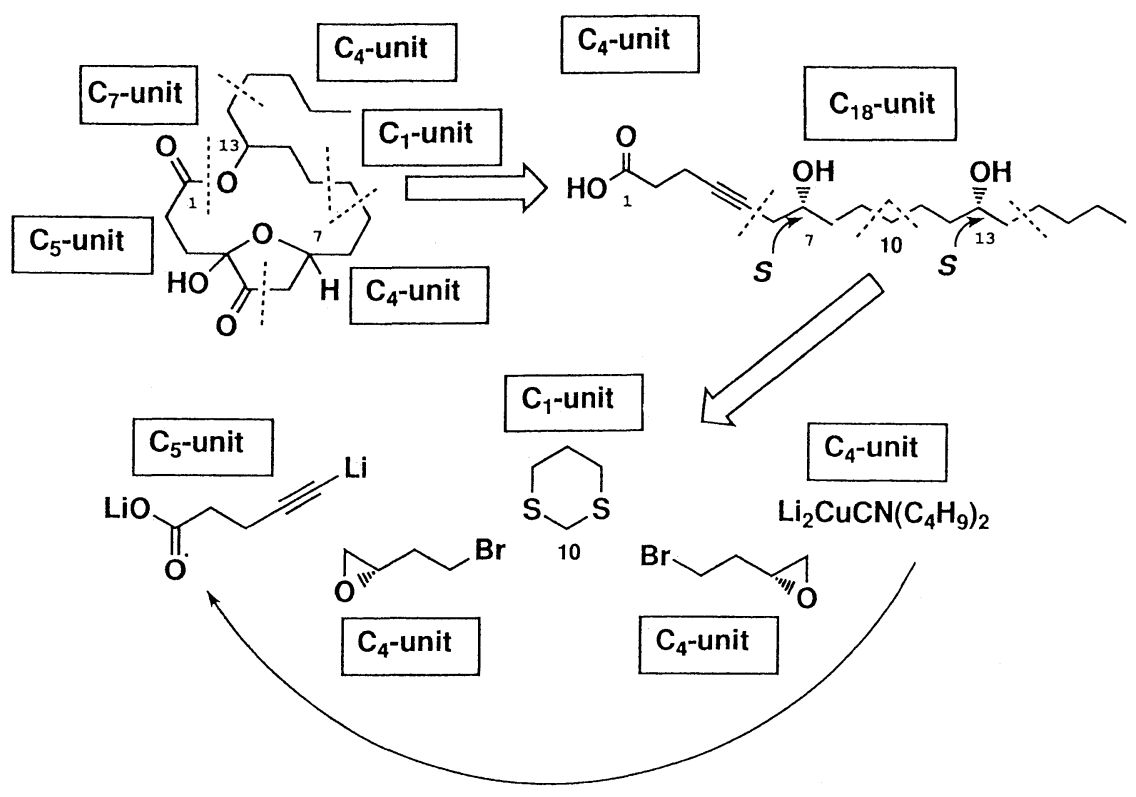

Fig. 5-1 Retrosynthetic scheme of gloeosporones by Seebach et al. ${ }^{13,21)}$

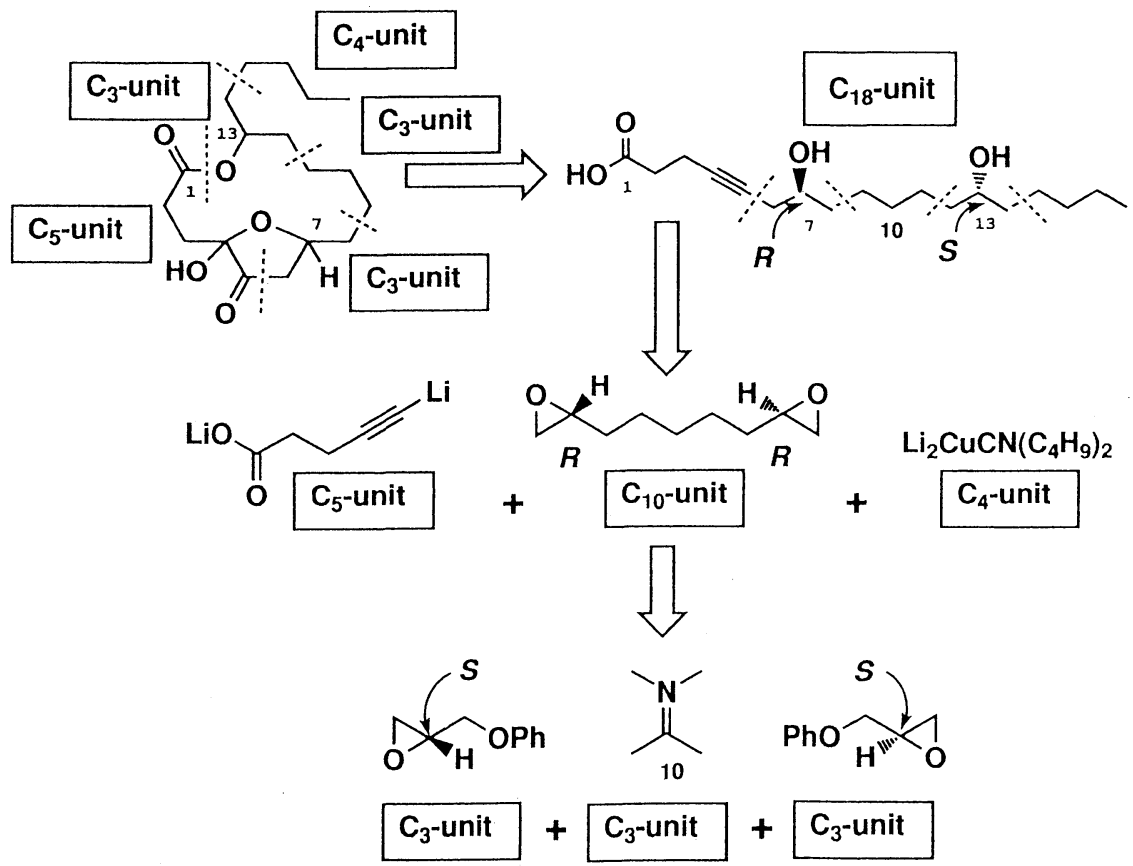

Fig. 5-2 Retrosynthetic scheme of (-)-gloeosporone by Takano et al. ${ }^{19)}$

fungus, we developed a new bioassay technique to detect their self-inhibitors including gloeosporone. Presently, we have not detected the compound from all the strains of collected anthracnose fungi, including $C$. gloeosporiodes f. sp. jussiaea, the same strain from which gloeosporone had originally been isolated. From concentrated biological and chemical experiments, we isolated the three genuine active compounds from the same fungal strain instead of gloeosporone. The results of spectrometric analyses using MS, IR and ${ }^{1} \mathrm{H}-\mathrm{NMR}$ in- dicated that the structures of the compounds are indole derivatives (7a), (7b) and (7c), respectively, which were named CG-SI-1, 2 and 3. ${ }^{24)}$ Isolation of (7a) and (7b) was the first example from a natural source, but syntheses of them had been reported by Tacconi. ${ }^{25)}$ The inhibitory activity of the synthesized compounds against conidial germination exhibited the same activities as those of the natural ones and (7c) was an antipode of indolepropionic acid isolated from Claviceps porpurea. ${ }^{26)}$ Quantitative analyses of the isolated three compounds in 


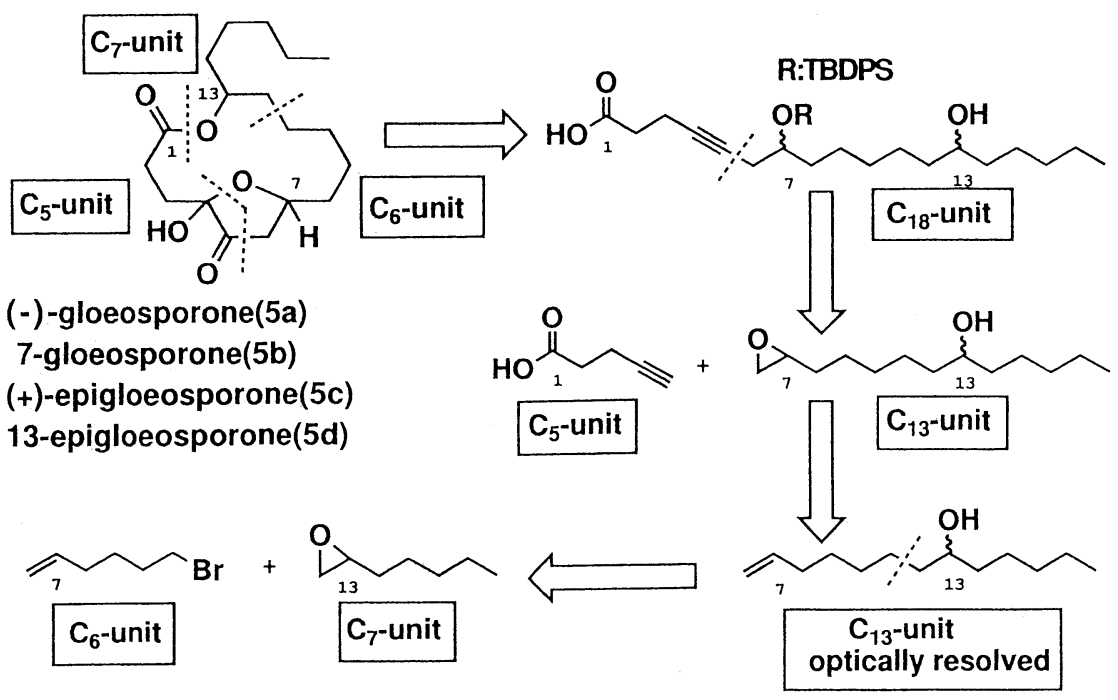

Fig. 5-3 Retrosynthetic scheme of gloeosporones by Irie et al. ${ }^{23)}$<smiles>C/C=C1\C(=O)Nc2ccccc21</smiles>

$7 a$<smiles>CC=C1C(=O)Nc2ccccc21</smiles>

$7 b$<smiles>C[C@@H](C(=O)O)c1c[nH]c2ccccc12</smiles>

$7 c$

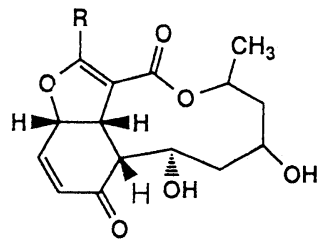<smiles>[R]=C/C=C\C=C/C=C\C</smiles>

$8 b$<smiles>C/C=C/C=C/C=O</smiles>

9<smiles>COC1=C(NC(C)C(=O)O)CC(C)(O)CC1=O</smiles>

10

Fig. 6 Self-inhibitors from anthracnose fungi : CG-SI-1 (7a), 2 (7b), 3 (7c), colletofragarone A1 (8a) and (8b), 2,4-hexadienal (9), and mycosporine-alanine (10).

fluids from suspended conidia of the fungus indicated that they are contained in sufficient concentrations to inhibit germination of the conidia. Detailed biological experiments also indicated that they only inhibit conidial germination, and do not affect hyphal growth. These results provide conclusive evidence that the isolated compounds are genuine self-inhibitors of $C$. gloeosporiodes f. sp. jussiaea. It is well known that the production of fungal metabolites is largely dependent on their cultured conditions. The natural gloeosporone has not yet been detected in the metabolites of $C$. gloeosporiodes f. sp. jussiaea, based on cochromatography with the synthesized authentic specimen. In addition, the results of the bioassay shown in Table 2 indicated that all of the synthesized isomers of gloeosporone $\mathbf{6 a - d}$ including (-)gloeosporone exhibited almost no inhibitory activity against conidial germination, whereas the indole derivatives $7 \mathbf{a}$ and $\mathbf{7 b}$ exhibited strong activity under the same conditions. Accordingly, it is not likely that gloeosporone acts as a self-inhibitor despite its attention from natural product chemistry.

2.2 Germination self-inhibitors from conidia of Colletotrichum fragariae

Distribution of CG-SI-1, 2 and 3 as self-inhibitors among anthracnose fungi was investigated using the collected 16 strains of the fungi (9 Colletotrichum and 7 
Glomerella species). As a result, these three compounds were detected in both the cultured medium and the conidial germination fluid of $C$. fragariae, the strawberry anthracnose pathogen, as well as $C$. gloeosporioides f. sp. jussiaea. This fact implies that they also play a role as germination self-inhibitors in that fungus strain. ${ }^{2,24}$ Results of precise bioassays indicated the presence of an additional five self-inhibitors over the original CG-SI-1, 2 and 3 in the cultured medium of $C$. fragariae. This urged us to perform further chemical research on the self-inhibitors from the fungus. ${ }^{27)}$

Two relatively stable compounds were successfully isolated among the newly discovered self-inhibitors, the remainder of which were not analyzed because their unstable or volatile characters made it difficult to purify and isolate them. The two isolated compounds were named colletofragarones A1 and A2. Mass spectrometric data indicated they have same molecular formula, $\mathrm{C}_{22} \mathrm{H}_{26} \mathrm{O}_{6}$ (MW 386). The structures for colletofragarones $\mathrm{A} 1$ and $\mathrm{A} 2$ shown in $8 \mathbf{a}$ and $8 \mathbf{b}$ were proposed respectively, based on further detailed analyses of NMR data, ${ }^{27)}$ which indicated they are a fused threerings compound composed of a ten-membered lactone and a benzofuran derivative substituted with a geometric isomerism of a conjugated trienyl group. A mixture of these isomers $(\mathbf{8 a}: \mathbf{8 b}=c a .1: 1)$ inhibited conidial germination of $C$. fragariae with an $\mathrm{ED}_{50}$ of $20 \mu \mathrm{g} / \mathrm{ml}$. The distribution of the new compounds $\mathbf{8 a}$ and $\mathbf{8 b}$ was also investigated in the collected strains of anthracnose fungi. The result of chromatographic surveys indicated that, besides $C$. fragariae, these two compounds are present only in Glomeralla fusarioides. In this connection, neither of CG-SI-1, 2 nor 3 was detected in these collected species.

Moreover, two of the other three unidentified selfinhibitors from $C$. fragariae were considered to be the same molecular weight as colletofragarone based on LC-MS analyses of partially purified samples. However, their structure elucidation has not been performed yet because of their highly unstable character which causes decomposition during isolation.

The last of the unidentified self-inhibitors is a highly volatile compound, while all of the self-inhibitors described above were polar compound diffusible in water. Previous articles reported that nonpolar volatile compounds also participate in endogenous regulation of spore germination. Volatility might provide an advantage for a temporal action of self-inhibitors, but in some cases isolation and structural elucidation of unknown volatile compounds presents such experimental difficulty as described in the followings. Robinson et al. observed in Geotrichum candida that several volatile compounds were produced by a high spore density of the fungus and inhibit spore germination as well as hyphal growth. However, experimental difficulties hampered detailed chemical research except the structure elucidation of one component, trimethylamine. ${ }^{28-30}$ Leite $e t$ al. described the presence of a volatile self-inhibitor, together with mycosporine alanine which will be discussed later, and attempted its isolation and structure elucidation, which resulted in an indication that the active principle might be a kind of acetate derivative. ${ }^{31)}$ Additionally, Robinson et al. reported several examples of volatile compounds from Fusarium oxysporum, such as acetaldehyde and others, which are involved in promotion or inhibition of the spore germination independent of the conidial population. ${ }^{32-35)}$

We purified a volatile active principle produced in the culture medium of $C$. fragariae. The structure was identified as $(2 E, 4 E)$-2,4-hexadienal (9) from its mass spectral and ${ }^{1} \mathrm{H}-\mathrm{NMR}$ data. ${ }^{36)}$ Under tightly sealed condition, this compound inhibited conidial germination with an $\mathrm{ED}_{50}$ value of $30 \mu \mathrm{g} / \mathrm{ml}$, whereas under unsealed condition its concentration in water decreases over time because of its volatility to release the conidia to germinate. This result explains both the temporal and reversible action of this compound as a self-inhibitor.

Colletofragarone A1 and A2 and CG-SI- 1 and 2 were detected in the conidia suspension solution of $C$. fragariae. This fact indicates that these four compound are actually secreted from the conidia and play an important role in regulation of conidial germination. Two unknown compounds with molecular weights estimated to be the same as those of colletofragarones were not detected in the same solution probably because of their unstable nature and their scant content. The presence of 2 , 4-hexadienal has not been yet confirmed in the conidia suspension. But this compound would be the first example of a volatile self-inhibitor if its presence in the conidia suspension was confirmed.

\subsection{Germination self-inhibitors from conidia of other anthracnose fungi}

The species producing CG-SIs (indole derivatives) and colletofragarones are restricted only to a few of the collected 16 anthracnose strains. Accordingly, other species are likely to produce different compounds as their self-inhibitors.

Among them, mycosporine-alanine was reported to be a self-inhibitor from $C$. graminicola $^{31)}$ We also observed germination inhibition inversely dependent on conidial concentration in the cucumber anthracnose pathogen, $C$. lagenarium. Screening for a compound exhibiting inhibitory activity against conidial germination from the cultured medium of the fungus resulted in the isolation of $\alpha$-eleostearic acid, which is a fatty acid composed of 18 carbons with a conjugated triene. ${ }^{36)}$ This fatty acid is so unstable that it is oxidized even in the atmosphere. The result of in vitro conidial germination tests suggested that the actual active principle might be an oxidized compound derived from $\alpha$-eleostearic acid 


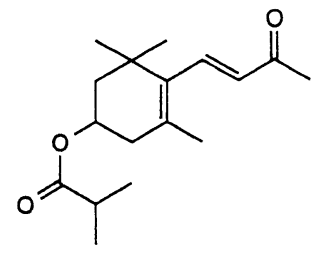

11

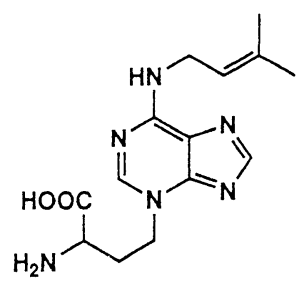

12
Fig. 7 Self-inhibitors from other fungi : quiesone (11) and discadenine (12).

owing to its unstable character, the structure of which has not been confirmed. Additionally, the conidia treated with a solution of $\alpha$-eleostearic acid could not recover germination by washing with water. This fact demands further investigation for us to regard the compound as a self-inhibitor.

As described before, solutions of conidial suspensions are analyzed to examine whether the isolated germination-inhibitory compounds from the cultured medium are actually secreted from conidia. In rust fungi, uredospores are easily collected, because of their large size, by shaking them off from the surface of host plant leaf. However in anthracnose fungi, it is rather difficult to collect conidia because of their small size not only from host, but also from their culture on artificial media. Usually, conidia of anthracnose fungi were harvested by gently brushing plate cultures after addition of a small amount of distilled water and collected by filtration through three layers of gauze followed by centrifugation. The prepared conidial pellet was washed twice by resuspension and centrifuged in distilled water before use. In the conidial suspension prepared according to such procedures, it may be impossible to avoid contamination with metabolites from unremoved small mycelial fragments. Because of this, it can not be directly concluded that the isolated compound is a genuine self-inhibitor contained in conidia, even though it was detected in the conidial suspension. With respect to the self-inhibitors from anthracnose fungi described here, with a few exceptions, their presence is confirmed in conidial suspension. However, considering the problems with the analytical procedures described above, further developments in analytical methodology is necessary for a direct detection of their distribution in the conidium itself in order to investigate their role in regulation of spore germination.

As described in the introduction, it is evident that water is an indispensable factor for spores to germinate. Permeation of water into spore provides favorable endogenous biochemical circumstances to initiate germination. Additionally, water surrounding spores acts as a solvent to release their endogenous germination inhibitor. In this article, we described the possibility that endogenous self-inhibitors play an important role in spore germination of some rust and anthracnose fungi. In addition to the examples described above, the occurrence of self-inhibitors has been reported in over 60 species, but the chemical structures have been elucidated in only two cases ; 5 -isobutyloxy- $\beta$-ionone (quiesone, 11) from tobacco downy mildew, Perenospora tabacina ${ }^{37)}$ and discadenine (12) from the cellular slime mold, Dyctyosterium discoideum. ${ }^{38)}$ On the other hand, density-dependent spore germination has not been observed in most fungi in nature. The lack of evidence for self-inhibitors might be attributed to the fact that these inhibitors rapidly degrade or disappear owing to high instability or volatility, and then makes it difficult to detect the actual self-inhibitor after diffusion into the environment. Further developments in this field are expected to solve the problem.

Among the self-inhibitors shown above, some structures $(\mathbf{1}, \mathbf{2}, \mathbf{7 a}-\mathbf{c})$ suggest a structural relationship to auxin, and another (12) to cytokinin. It is well known that gibberellin and abscisic acid are not only produced by higher plants but also by fungi. To adapt to a diversity of environments eumycetes, which are regarded as lower plants, have utilized a part of their secondary metabolites to regulate homeostasis in their life cycle. What kind of substances have been selected as endogenous control factors during the long evolutionary process from eumycetes to higher plants? We are convinced that the investigation of the evolution of secondary metabolites will become one of the most important subjects in the chemistry of natural products.

\section{ACKNOWLEDGMENTS}

The authors thank Drs. Thomas J. Wolpert and Shigeyuki Mayama for reviewing the manuscript. The work in our laboratory was in part supported by a grant from Mitsubishi Foundation, Japan.

\section{REFERENCES}

1) J. K. Sharma \& S. Sinha : "Ecology of Leaf Surface Microorganisms," ed. by T. F. Preece \& C. H. Dickinson, Academic Press, p. 597, 1971

2) M. Inoue, N. Mori, H. Yamanaka, T. Tsurushima, H. Miyagawa \& T. Ueno: J. Chem. Ecol. 22, 2111 (1996)

3) P. J. Allen : Phytopathology 45, 259 (1955)

4) V. Macko, R. C. Staples, P. J. Allen \& J. A. A. Renwick: Science 170, 835 (1971)

5) N. Naito, T. Tani \& Y. Sato: Ann. Phytopath. Soc. Jpn. 24, 234 (1959)

6) T. Tsurusima, T. Ueno, H. Fukami, S. Mayama \& T. Tani : Agric. Biol. Chem. 48, 2147 (1984)

7) V. Macko, R. C. Staples, J. A. A. Renwick \& J. Pirone : Physiol. Plant Pathol. 2, 347 (1972)

8) A. S. Foudin \& V. Macko: Phytopathology 64, 990 (1974)

9) V. Macko, E. J. Trione \& S. A. Young: Phytopathology 67, 1473 (1977)

10) V. Macko, R. C. Staples, H. Gershon \& J. A. A. Renwick: 
Science 173, 835 (1971)

11) T. Tsurushima, S. Mayama, T. Tani, T. Ueno \& H. Fukami : Ann. Phytopathol. Soc. Jpn. 50, 582 (1984)

12) C. W. Edgerton: La. Agric. Exp. Sta. Bull. 119, 1 (1910)

13) A. R. Lax, G. E. Templeton \& W. L. Meyer: Phytopathology 75, 386 (1985)

14) W. L. Meyer, A. R. Lax, G. E. Templeton \& M. J. Branonne: Tetrahedron Lett. 24, 5059 (1983)

15) R. W. Carling \& A. B. Holmes : Tetrahedron Lett. 27, 6133 (1986)

16) M. Mortimore, G. S. Cockerill, P. Kocienski \& R. Treadgold : Tetrahedron Lett. 28, 3747 (1987)

17) W. L. Meyer, W. B. Schweizer, A. K. Beck, W. Scheifele, D. Seebach, S. L. Schreiber \& S. E. Kelly: Helv. Chim. Acta 70, 281 (1987)

18) G. Adam, R. Zibuck \& D. Seebach : J. Am. Chem. Soc. 109, 6176 (1987)

19) S. Takano, Y. Shimazaki, M. Takahashi \& K. Ogasawara : J. Chem. Soc. Chem. Commun. 1004 (1988)

20) S. L. Schreiber, S. E. Kelly, J. A. Parco, Jr., T. Sammakia \& E. M. Suh : J. Am. Chem. Soc. 110, 6210 (1988)

21) D. Seebach, G. Adam, R. Zibuck, W. Simon, M. Rouilly, W. L. Meyer, J. F. Hinton, T. A. Ptivett, G. E. Templeton, D. K. Heiny, U. Gisi \& H. Binder : Liebigs Ann. Chem. 1233 (1989)

22) D. Seebach, G. Adam, C. Bussche-Hnnefeld, U. Gisi \& H. Binder : Liebigs Ann. Chem. 1007 (1990)

23) M. Matsushita, M. Yoshida, Y. Zhang, M. Miyashita, H. Irie, T. Ueno \& T. Tsurushima : Chem. Pharm. Bull. 40, 524 (1992).

24) T. Tsurushima, T. Ueno, H. Fukami, H. Irie \& M, Inoue : Mol. Plant-Microbe Interactions 8, 652 (1995)

25) G. Tacconi, L. D. Maggi, P. Rihgetti \& G. Desmoni : J. Chem. Soc. Perkin II 150 (1975)

26) T. Yamano: Nippon Nogeikagaku Kaishi 35, 1284 (1961) (in Japanese)

27) M. Inoue, H. Takenaka, T. Tsurushima, H. Miyagawa \& T. Ueno: Tetrahedron Lett. 37, 5731 (1996)

28) D. Park \& P. M. Robinson : Trans. Brit. Mycol. Soc. 54, 83 (1970)
29) N. D. McKee \& P. M. Robinson : Trans. Brit. Mycol. Soc. 91, 157 (1988)

30) P. M. Robinson, N. D. McKee, L. A. A. Thomson, D. B. Haper \& J. T. G. Hamilton: Mycol. Res. 93, 214 (1989)

31) B. Leite \& R. L. Nicholson: Mycologia 85, 945 (1993)

32) P. M. Robinson, M. K. Garrett \& D. Park: Trans. Brit. Mycol. Soc. 49, 639 (1966)

33) P. M. Robinson, M. K. Garrett \& D. Park: Trans. Brit. Mycol. Soc. 51, 113 (1969)

34) M. K. Garrett \& P. M. Robinson : Arch. Microbiol. 67, 370 (1969)

35) P. M. Robinson \& M. K. Garrett: Trans. Brit. Mycol. Soc. 52, 293 (1969)

36) H. Yamanaka, M. Inoue, N. Mori, H. Miyagawa \& $T$. Ueno: Abstracts of Papers, the 21st Annual Meeting of the Pesticide Science Society of Japan, Okinawa, 1996, p. 101

37) R. A. Leppik, D. W. Holloman \& W. Bottomley: Phytochemistry 11, 2055 (1972)

38) H. Abe, M. Uchiyama, Y. Tanaka \& H. Saitou : Tetrahedron Lett. 42, 3807 (1976)

\section{要 約}

\section{植物病原菌の自己発芽抑制物質}

上野民夫，宮川 恒，鶴島 鉄，井上雅文

胞子の発芽は菌類にとって新しいコロニーを形成するた めの最初の活動である、胞子が発芽するときには，これを 規制するいくつかの要因がある，温度・湿度・光・酸素量 などの無機的要因のほかに，発芽機構を制御する化学的要 因がある，ある場合には，植物が分泌する化学物質が胞子 の発芽を促進するが，胞子自身が自己の発芽を抑制する物 質を含有していて，これを外界に放出することによって休 眠状態から覚醒することが知られている。このような物質 は自己発芽抑制物質と呼ばれ，高い静菌作用を示す新しい 天然生理活性物質である。本論文では植物病原菌を題材に 系状菌胞子の発芽機構を解明する目的で我々が展開してき た研究を中心に，天然物化学的な視野に立って解説した. 